\title{
Prevalence of Blood Protozoa Disease on Cattle and Buffalo in Moyo Hilir Sub-District, Sumbawa District West Nusa Tenggara
}

\author{
Prevalensi Penyakit Protozoa Darah pada Sapi dan Kerbau di Kecamatan Moyo Hilir \\ Kabupaten Sumbawa Nusa Tenggara Barat \\ ${ }^{1)}$ Melani Anggraini, ${ }^{2}$ Hardany Primarizky, ${ }^{3)}$ Mufasirin, ${ }^{3)}$ Lucia Tri Suwanti, 3) Poedji Hastutiek, \\ ${ }^{3)}$ Setiawan Koesdarto \\ ${ }^{1)}$ Student, Faculty of Veterinary Medicine, Universitas Airlangga. \\ ${ }^{2)}$ Department of Veterinary Clinic, Faculty of Veterinary Medicine, Universitas Airlangga. \\ 3) Department of Veterinary Parasitology, Faculty of Veterinary Medicine, Universitas Airlangga. \\ Received: 25-02-2019, Accepted: 10-03-2019, Published Online: 19-03-2019
}

\begin{abstract}
The aim of this research was to determine the type and prevalence of blood protozoa disease on cattle and buffalo in Moyo Hilir sub-district, Sumbawa District, Wes Nusa Tenggara. This research was taken on july until December 2018. This research used a nonexperimental method through an observation study. The samples of this research were made in thin blood smear using $20 \%$ Giemsa's stain and all samples were from 200 blood of cattle and buffalo in Moyo Hilir sub-district, Sumbawa District, West Nusa Tenggara. The results showed that the prevalence of blood protozoa disease was 11.5 Based on the type of blood protozoa, the highest prevalence was Anaplasma sp. (11\%), followed by Theileria sp. (0.5\%), while Babesia sp. And Trypanosoma sp. Were not found. Based on the livestock types, the prevalence in buffalo was higher (17\%)than cttle (6\%). Based on sex the prevalence in female was higher $(12.6 \%)$ than male (10.11\%). Based on age of livestock, the prevalance of livestock with age $>2$ years old was higher $(13.33 \%)$ than livestock with age $\leq 2$ years old $(10.4 \%)$ based on the location of the village, blood protozoa disease were only found in Olatrawa village $(17.85 \%)$ and Serading village (17.82\%), while in Kakiang and Moyo village were not found. The conclusion of this research indicate that prevalence of blood protozoa disease was $11.5 \%$ and only Anaplasma sp. And Theileria sp. Were found.
\end{abstract}

Key words : anaplasmosis, babesiosis, theileriosis, trypanosomiasis, Sumbawa District.

\section{Pendahuluan}

Kabupaten Sumbawa menjadikan sektor peternakan sebagai salah satu sektor unggulan. Sebagian besar mata pencarian penduduk di pulau Sumbawa ada pada sektor peternakan. Salah satu kecamatan di Kabupaten Sumbawa adalah Kecamatan Moyo Hilir. Kecamatan ini memiliki populasi sapi dan kerbau paling tinggi diantara 24 kecamatan di Kabupaten Sumbawa yaitu berjumlah 30.529 ekor (BPS Kabupaten Sumbawa, 2018). Banyaknya lahan yang dapat digunakan untuk ternak dan hamparan padang rumput atau padang penggembalaan sangat mendukung masyarakat untuk beternak. Meskipun dukungan alam yang baik untuk memelihara ternak di pulau Sumbawa, tetapi ada beberapa hambatan yaitu timbulnya berbagai penyakit yang menyerang ternak. Salah satu penyakit yang sering menyerang ternak yaitu penyakit protozoa darah. Penyakit protozoa darah dapat bersifat kronis dan akut yang membahayakan ternak. Penyakit protozoa darah yang berjalan kronis tidak mematikan ternak secara langsung tetapi dapat menyebabkan penurunan berat badan, peningkatan kerentanan terhadap penyakit lain dan penurunan tingkat reproduksi sehingga merugikan secara ekonomi. Penyakit protozoa darah yang sering menyerang ternak yaitu surra, babesiosis, theileriosis dan anaplasmosis.

Surra adalah penyakit protozoa darah yang disebabkan oleh infeksi Trypanosoma evansi. Penyakit ini ditularkan oleh lalat penghisap darah. Penyakit protozoa darah lainnya yaitu babesiosis, theileriosis dan anaplasmosis. Babesiosis dan theileriosis ditularkan oleh caplak, sedangkan anaplasmosis ditularkan oleh lalat penghisap darah dan caplak. Caplak dominan ditemukan pada daerah yang memiliki kelembapan diatas $70 \%$ dan curah hujan yang tinggi $\pm 1.000 \mathrm{~mm} /$ tahun (Leliana dan Rizalsyah, 2015). 
Kondisi iklim Kabupaten Sumbawa memiliki kelembapan diatas $70 \%$ dengan curah hujan pada tahun 2017 sebesar $\pm 1.884 \mathrm{~mm}$ (BPS Kabupaten Sumbawa, 2018a). Kondisi ini mendukung perkembangan hidup caplak. Lingkungan yang mendukung perkembangan siklus hidup caplak akan mempermudah caplak untuk berkembang biak dan menyebabkan kemungkin infeksi protozoa darah pada ternak lebih tinggi.

Mastra (2011) telah melakukan penelitian di pulau Sumbawa, sebanyak $36(21,55 \%)$ dari 167 serum sapi dan kerbau positif mengandung antibodi terhadap Trypanosoma evansi. Laksmi dkk. (2016) juga telah melakukan penelitian mengenai kejadian Surra, ditemukan sebanyak 1o sampel positif surra di Kabupaten Sumbawa. Kemudian ditahun selanjutnya Laksmi dkk. (2017) juga medeteksi sebanyak 4 dari 37 sampel positif surra di Kecamatan Moyo Hilir Kabupaten Sumbawa, NTB. Penyakit protozoa darah lain yang sering menyerang ternak adalah babesiosis, theileriosis dan anaplasmosis. Menurut penelitian yang telah dilakukan oleh Anggraini (2013), prevalensi anaplasmosis, theileriosis, dan babesiosis pada sapi di Kabupaten Sumedang, Jawa Barat berturutturut berjumlah $38.8 \%$, 33.8\%, dan $22,3 \%$. Laksmi dkk. (2016) juga telah melakukan penelitian pada sapi di Kabupaten Dompu, NTB ditemukan sebanyak satu sampel positif theileriosis. Selain itu, Guswanto et al. (2017) juga telah mendeteksi babesiosis sebanyak 16 (94,1\%) dari total 17 sampel sapi di Kabupaten Dompu, Nusa Tenggara Barat dengan metode EnzymeLinked Immunosorbent Assay (ELISA).

Data mengenai penyakit protozoa darah yang telah diuraikan sebelumnya menunjukkan bahwa di Nusa Tenggara Barat (NTB), penyakit protozoa darah hampir setiap tahun terjadi dalam jumlah yang tinggi ataupun rendah. Data-data mengenai penyakit protozoa darah di Kabupaten Sumbawa khususnya pada tingkat kecamatan perlu diperbarui setiap tahunnya agar memudahkan pencegahan penularan penyakit. Berdasarkan uraian tersebut, perlu dilakukan penelitian mengenai prevalensi penyakit protozoa darah pada sapi dan kerbau di Kecamatan Moyo Hilir Kabupaten Sumbawa, Nusa Tenggara Barat. Hasil penelitian ini dapat digunakan untuk melakukan pencegahan penyakit protozoa darah pada sapi dan kerbau, sehingga kerugian yang lebih besar dapat dihindari.

\section{Metode Penelitian}

Rancangan penelitian ini menggunakan metode non-eksperimental yang berjenis kajian survei. Sampel dalam penelitian ini adalah sampel darah perifer sapi dan kerbau sejumlah 200 ekor yang diambil dari berbagai desa di Kecamatan Moyohilir Kabupaten Sumbawa, Nusa Tenggara Barat. Sampel darah yang telah diambil, kemudian dibawa ke Laboratorium Dinas Peternakan dan Kesehatan Hewan Kabupaten Sumbawa untuk diwarnai. Setelah itu sampel diperiksa di Laboratorium Parasitologi Fakultas Kedokteran Hewan Universitas Airlangga. Alat dan bahan yang digunakan dalam penelitian ini yaitu alkhol $70 \%$, metanol absolut, pewarna Giemsa $20 \%$, aquadest, oil emersi, jarum suntik ukuran $18 \mathrm{~g}$, gelas objek, boks penyimpanan, Staining jar, dan mikroskop. Langkah pewarnaan Giemsa yaitu preparat hapusan darah yang telah dibuat di fiksasi dengan metanol absolut selama 3 menit. Setelah itu praparat di masukkan ke dalam larutan Giemsa 10-20 \% selama 30 menit. Preparat diangkat dan dicuci dengan air mengalir sampai air cucian bening. Kemudian, preparat hapusan darah dikeringkan dengan meletakkan gelas objek posisi berdiri pada bidang miring atau diangin-anginkan. Setelah itu preparat diperiksa menggunakan mikroskop degan perbesaran 1000 kali. Sampel dianggap positif apabila ditemukan adanya protozoa darah baik infeksi tunggal ataupun infeksi campura. Data sampel positif dan negatif yang diperolah disajikan secara deskriptif dan dianalisis berdasarkan jenis protozoa darah, jenis ternak, jenis kelamin, umur, dan letak desa. Prevalensi dihitung berdasarkan sampel +/ total sampel dinyatakan dalam $\%$.

\section{Hasil dan Pembahasan}

Hasil pemeriksaan dari 200 sampel darah sapi dan kerbau ditemukan beberapa bentuk protozoa darah yaitu Anaplasma sp. dan Theileria sp. sedangkan Trypanosoma sp. dan Babesia sp. tidak ditemukan. Hasil pengamatan terlihat adanya protozoa darah dengan bentuk bulat, padat terletak di dalam dan tepi eritrosit yang merupakan bentukan dari Anaplasma marginale, terlihat pada Gambar 1. Selain itu, ditemukan juga bentukan kecil, bulat, ovoid, tidak beraturan dengan sitoplasma berwarna biru di dalam eritrosit yang merupakan bentuk dari Theileria sp., terlihat pada Gambar 2.

Infeksi protozoa darah yang ditemukan dalam penelitian ini paling banyak oleh Anaplasma sp. diikuti Theileria sp. sedangkan 
Babesia sp. dan Trypanosoma sp. tidak ditemukan. Hal ini dapat disebabkan karena vektor anaplasmosis lebih luas yaitu dapat ditularkan oleh caplak (secara biologis), lalat penghisap darah (secara mekanik) dan dapat ditularkan pada saat kastrasi, pemotongan tanduk (dehorning), vaksinasi atau waktu pengambilan darah (Suwanti dkk., 2012), sedangkan pada theileriosis, babesiosis hanya dapat ditularkan oleh caplak dan surra hanya dapat ditularkan oleh lalat penghisap darah. Vektor anaplasmosis yang lebih luas dibandingkan dengan penyakit protozoa darah lain memungkinkan infeksi anaplasmosis pada ternak juga lebih tinggi dibandingkan theileriosis, babesiosis ataupun surra.

Hasil penelitian sampel darah ditemukan sebanyak 23 sampel positif terinfeksi protozoa darah, sehingga prevalensi penyakit protozoa darah pada sapi dan kerbau di Kecamatan Moyo Hilir Kabupaten Sumbawa, Nusa Tenggara Barat sebesar 11,5\%. Prevalensi protozoa darah yang ditemukan pada penelitian ini termasuk dalam kategori rendah. Rendahnya prevalensi protozoa darah dapat disebabkan oleh berbagai faktor antara lain musim dan curah hujan yang mempengaruhi vektor dan kondisi ternak. Proses pengambilan sampel penelitian ini dilakukan pada bulan Juli yang merupakan musim kemarau, dimana pada musim ini infestasi caplak rendah (Sulistyaningsih, 2016). Infestasi caplak rendah pada musim kemarau dapat disebabkan oleh kekeringan yang menganggu siklus hidup lalat penghisap darah. Telur lalat penghisap darah akan terhambat perkembangannya pada suhu rendah dan juga akan mati apabila terjadi kekeringan (Sasmita dkk., 2013). Siklus hidup lalat penghisap darah yang terganggu akan menyebabkan ternak yang terinfeksi protozoa darah juga rendah. Selain itu, rata-rata curah hujan yang terjadi pada bulan Juli di Kabupaten Sumbawa NTB termasuk dalam kategori rendah (o-50 mm) (Ridwan, 2018). Rendahnya curah hujan dapat menghambat siklus hidup vektor penyakit protozoa darah. Tabanus rubidus, salah satu lalat penghisap darah akan meletakkan telurnya didekat air, biasanya dibagian bawa daun tanaman (Sasmita dkk., 2013). Apabila curah hujan rendah akan menghambat prekembangan dari vektor dan menyebabkan kemungkinan infeksi protozoa darah terhadap ternak juga sedikit.

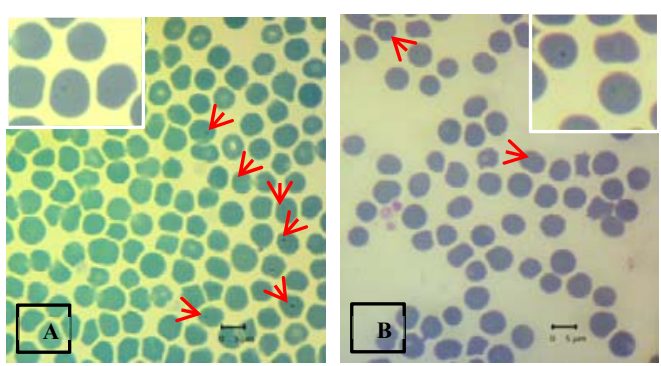

Gambar 1 Anaplasma marginale perbesaran 1000 kali, pewarnaan Giemsa. A= sampel darah kerbau dan $\mathrm{B}=$ sampel darah sapi di desa Serading Kecamatan Moyo Hilir Kabupaten Sumbawa NTB

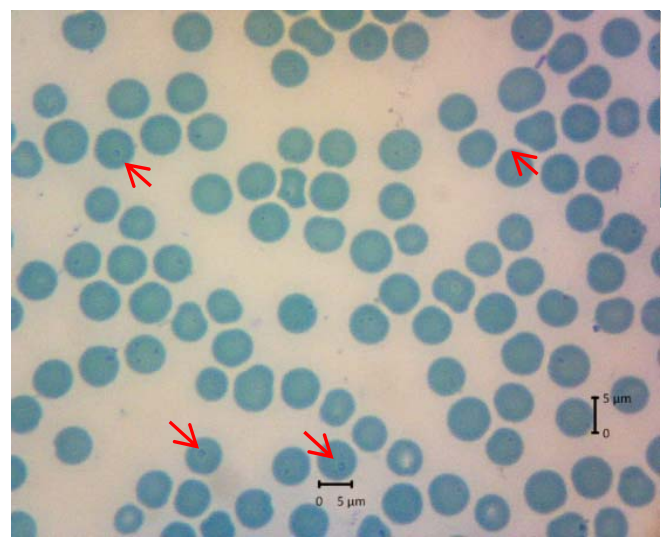

Gambar 2 Theileria $s p$. perbesaran 1000 kali dengan pewarnaan Giemsa pada sampel darah kerbau di desa Olatrawa Kecamatan Moyo Hilir Kabupaten Sumbawa NTB

Hasil pemeriksaan dari total 100 sampel darah sapi yang diambil ditemukan enam sampel positif terinfeksi protozoa darah, sehingga prevalensi penyakit protozoa darah pada sapi di Kecamatan Moyo Hilir Kabupaten Sumbawa sebesar 6\%, sedangkan hasil pemeriksaan pada 100 sampel darah kerbau ditemukan 17 sampel positif, sehingga prevalensi penyakit protozoa darah pada kerbau di Kecamatan Moyo Hilir Kabupaten Sumbawa sebesar $17 \%$. Rincian hasil penelitan pada sapi dan kerbau dapat dilihat pada Tabel 1. 
Tabel 1 Prevalensi Penyakit Protozoa Darah pada Sapi dan Kerbau di Kecamatan Moyo Hilir Kabupaten Sumbawa NTB

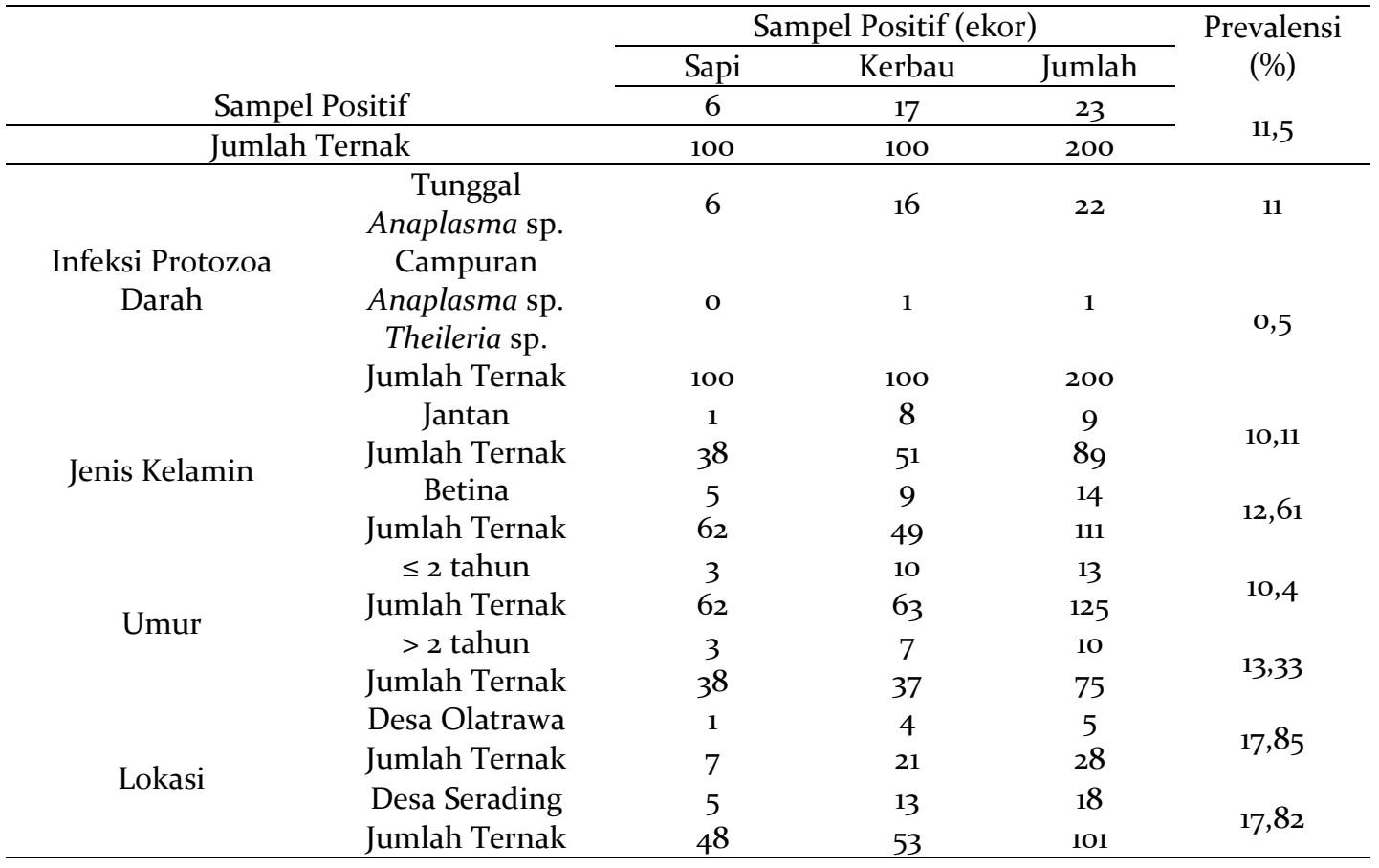

Sampel darah kerbau dalam penelitian ini mengalami infeksi campuran oleh Theileria sp. dan Anaplasma sp. Hal ini dapat terjadi karena adanya kesamaan vektor antara theileriosis dan anaplasmosis yaitu sama-sama dapat ditularkan oleh caplak, sehingga dalam infeksi protozoa darah dapat terjadi secara bersamaan atau terpisah dalam satu ternak.

Nusa Tenggara Barat salah satu provinsi endemis surra tetapi dalam penelitian ini tidak ditemukan sampel positif surra. Hal ini dapat terjadi karena pengambilan sampel yang dilakukan pada bulan Juli, dimana curah hujan relatif rendah dan suhu yang cukup tinggi dapat menghambat perkembangan vektor, sehingga populasi vektor sedikit dan ternak yang terinfeksi juga sedikit. Selain itu, dapat juga disebabkan karena kerbau dan sapi telah terinfeksi tetapi pada saat pengambilan sampel darah, ternak dalam keadaan tingkat parasitemia rendah, sehingga dalam pemeriksaan ulas darah tidak ditemukan parasit. Selain itu, dapat juga disebabkan oleh kelemahan metode yang digunakan untuk mendiagnosis ternak. Pemeriksaan ulas darah tipis yang digunakan untuk diagnosis dalam penelitian ini merupakan uji laboratoris dengan tingkat sensitivitas rendah. Apabila ternak yang diambil darahnya memiliki tingkat parasitemia yang rendah maka sulit untuk menemukan parasit dengan metode ulas darah. Pemeriksaan ulas darah dengan pewarnaan Giemsa sering digunakan untuk diagnosis protozoa darah di lapangan karena merupakan teknik diagnosis yang sederhana, cepat dan membutuhkan biaya yang tidak mahal tetapi teknik diagnosis ini memiliki sensitivitas yang rendah sehingga sulit untuk mendeteksi ternak dengan tingkat parasitemia rendah (Chauhan, 2015).

Kerbau dan sapi yang diambil sampelnya dalam penelitian ini sama-sama dipelihara pada padang penggembalaan yang kering, tetapi prevalensi penyakit protozoa darah ditemukan lebih tinggi pada kerbau dibandingkan pada sapi. Hal ini dapat disebabkan oleh berbagai faktor diantaranya kondisi kandang dan pola hidup ternak. Kondisi kandang ternak dapat mempengaruhi kerentanan ternak terhadap penyakit. Kondisi kandang kerbau yang diambil sampelnya dalam penelitian ini ditemukan banyak tumpukan feses. Tumpukan feses yang banyak dapat menunjukkan terjadinya siklus hidup yang lancar dari vektor penyakit protozoa darah, sehingga lalat akan terus berkembang biak dan terus menginfeksi ternak. Salah satu lalat penghisap darah, Hematobia irritans akan meletakkan telurnya pada kotoran sapi atau kerbau yang masih segar (Sasmita dkk., 2013). Selain itu, pola hidup kerbau yang cenderung 
berkelompok dibanding sapi dapat mempermudah penularan penyakit protozoa darah antar kerbau dalam satu kelompok, sehingga pada kerbau dapat ditemukan prevalensi lebih tinggi dibanding sapi.

Infeksi protozoa darah berdasarkan jenis kelamin ditemukan lebih tinggi terjadi pada betina dibandingkan jantan. Hasil yang sama juga diperoleh pada penelitian Ardhiyanto (2015) bahwa rataan parasitemia pada kerbau betina lebih tinggi dibandingkan dengan kerbau jantan. Prevalensi yang lebih tinggi pada ternak betina dibandingkan jantan dapat terjadi karena ternak betina mengalami masa bunting, melahirkan dan laktasi dimana masa-masa tersebut menyebabkan stres yang cukup untuk mempermudah masuknya penyakit (Wibowo, 2014).

prevalensi protozoa darah berdasarkan umur ternak ditemukan lebih tinggi pada kategori umur $>\mathbf{2}$ tahun dibandingkan kategori umur $\leq \mathbf{2}$ tahun. Hasil yang sama juga diperoleh pada penelitian Kalman (2017), bahwa infeksi anaplasmosis pada sapi perah $\leq \mathbf{2}$ tahun sebesar 14,29\% dan ternak umur $>2$ tahun sebesar $15,19 \%$. Hal ini dapat terjadi karena ternak yang masih muda mendapatkan antibodi dari induk, dimana antibodi ini dapat melawan infeksi parasit, sehingga ternak yang masih muda lebih tahan terhadap infeksi parasit. Menurut Taylor (2007) antibodi induk yang terinfeksi protozoa darah dapat diberikan kepada anak ternak melalui kolostrum untuk melindungi anak ternak terhadap infeksi. Ternak kategori umur > 2 tahun mengalami infeksi protozoa darah yang lebih tinggi disebabkan karena mulai hilangnya kekebalan pasif yang didapatkan dari induk. Menurut Levine (dalam Wibowo, 2014), sistem kekebalan pasif sudah mulai hilang pada saat sapi berumur lebih dari satu tahun, sehingga ternak umur $>1$ tahun cenderung terinfeksi lebih tinggi dibandingkan ternak yang masih mendapatkan antibodi dari induk. Selain itu, ternak dewasa biasanya dipekerjakan atau difungsikan terlampau berat sehingga ternak akan mudah stres dan mempermudah infeksi protozoa darah. Ternak betina pada umur dewasa juga mulai bereproduksi yang dapat mempermudah infeksi parasit, sehingga infeksi pada ternak umur $>2$ tahun cukup tinggi dibanding ternak kategori umur $\leq \mathbf{2}$ tahun.

Infeksi protozoa darah ditemukan di desa Olatrawa dan Serading sedangkan di desa Kakiang dan Moyo tidak ditemukan. Hal ini dapat terjadi karena tempat penggembalaan ternak di desa Serading dan Olatrawa yang berada di padang penggembalaan yang kering.
Lokasi pemeliharaan ternak di padang pengembalaan yang kering dapat membuat ternak kesusahan mendapatkan rumput dan akan menyebabkan stress pada ternak. Keadaan ternak yang stres dapat mempermudah masuknya infeksi parasit darah (Wibowo, 2014).

\section{Daftar Pustaka}

Anggraini, N. F. 2013. Kajian Penyakit Parasit Darah pada Sapi Potong Peternakan Rakyat di Kecamatan Ujungjaya, Kabupaten Sumedang, Jawa Barat [Skripsi]. Fakultas Kedokteran Hewan. Institut Pertanian Bogor. Hal. 6.

Ardhiyanto, B. 2015. Parasitemia dan Diferensial Leukosit Kerbau Perah (Bubalus bubalis) Akibat Parasit Darah di Kabupaten Tapanuli Utara Sumatera Utara [Skripsi]. Fakultas Kedokteran Hewan. Institut Pertanian Bogor. Hal. 9 - 15.

BPS Kabupaten Sumbawa. 2018. Populasi Ternak di Kabupaten Sumbawa Menurut Kecamatan, 2016. https://sumbawakab.bps.go.id/dynamictable/2018/04/06/162/p opulasi-ternak-di-kabupaten sumba wamenurutkeca-matan-2016.html. $\left[\begin{array}{ll}12 & \text { Mei }\end{array}\right.$ 2018]

Chauhan, H. C., B. K. Patel, A. G. Bhagat, M. V. Patel, S. I. Patel, S. H. Raval, H. H. Panchasara, M. D. Shrimali. A. C. Patel, and B. S. Chandel. 2015. Comparison of Molecular and Microscopic Technique for Detection of Theileria Annulata from The Field Cases of Cattle. Vet. World. 8(11): 1370-1374.

Desquesnes, M., P. Holzmuller, De-Hua L., A. Dargantes, Zhao R.L., and S. Jittaplapong. 2013. Trypanosoma evansi and Surra: A Review and Perspectives on Origin, History, Distribution, Taxonomy, Morphology, Hosts, and Pathogenic Effects. Bio. Med. Research International. 2013: 1-22.

Dwiyani, N. P., N. Setiati, dan P. Widiyaningrum. 2014. Ektoparasit pada Ordo Artiodactyla di Taman Margasatwa Semarang. Unnes J. Life Sci. 3(2): 124-129.

Hornok, S., G. Foldvari, V. Elek, V. Naranjo, R. Farkas, and J. D. L. Fuente. 20o8. Molecular identification of Anaplasma marginale and rickettsial endosymbionts in blood-sucking flies (Diptera: Tabanidae, 
Muscidae) and hard ticks (Acari: Ixodidae). Vet. Parasitol. 154(3): 354-359.

Guswanto, A., P. Allamanda, E. S. Mariamah, S. Sodirun, P. E. Wibowo, L. Indrayani, R. H. Nugroho, I. K. Wirata, N. Jannah, L. P. Dias, H. P. Wirawan, R. Yanto, B. Tuvshintulga, T. Sivakumar, N. Yokoyama, and I. Garashi. 2017. Molecular and serological detection of bovine babesiosis in Indonesia. Bio. Med. Central. 10(1): 550-563.

Kalman, M. 2017. Infeksi Parasit Darah pada Sapi Perah di Kawasan Usaha Ternak (KUNAK) Cibungbulang Kabupaten Bogor [Skripsi]. Fakultas Kedokteran Hewan. Institut Pertanian Bogor. Hal. 10 - 12.

Laksmi, L. K. N., N. M. S. Handayani, D. Mustikawati, M. Septiani dan I. P. S. Budi. 2016. Peta Penyakit Hewan dan Mutu Porduk Hewan di Wilayah Provinsi Bali, Nusa Tenggara Barat dan Nusa Tenggara Timur Tahun 2016. Balai Besar Veteriner Denpasar. Denpasar.

Leliana dan T. Rizalsyah. 2015. Infestasi Caplak Ixodidae pada Sapi Lokal Aceh dan Balai Pembibitan Ternak Unggul dan Hijauan Pakan Ternak (BPTU - HPT) Indrapuri Kabupaten Aceh Besar. Jurnal Edukasi dan Sains Biologi. 4(2): 10 - 13.

Mastra, I. K. 2011. Seroprevalensi Trypanosomiasis di Pulau Sumbawa, Provinsi Nusa Tenggara Barat. Buletin Vet. BBVet Denpasar. 23(79) : 131-138.

Matondang, R. H. dan C. Talib. 2015. Pemanfaatan Ternak Kerbau Untuk Mendukung Peningkatan produksi Susu. J. Litbang Pert. 34(1): 41-49.

Mufasirin, N. D. R. Lastuti, E. Suprihati, dan L. T. Suwanti. 2016. Buku Ajar Ilmu Penyakit Protozoa. Airlangga University Press. Surabaya. 3-8.
OIE. 2013. Bovine Babesiosis. https://www.oie.i nt/fileadmin/Home/eng/AnimalHealthint heWorld/docs/pdf/Diseasecards/BOVINE BABESIOSIS.pdf. [14 Mei 2018]

Ridwan, M. 2018. Analisis Curah Hujan dan Sifat Hujan Bulan Juli 2018. https://www.bmkg .go.id/iklim/informasihujanbulanan.bmkg ?p=analisis-curah-hujandan-sifat-hujan bulan -juli - 2018\&lang=ID. [30 Desember 2018]

Sasmita, R., P. Hastutiek, A. Sunarso, dan M. Yunus. 2013. Buku Ajar Arthropoda Veteriner. Airlangga University Press. Surabaya. 71 .

Sulistyaningsih, S. 2016. Infestasi Caplak Boophilus microplus pada Sapi Potong di Kota Banjarbaru. Prosiding Seminar Nasional Inovasi Teknologi Pertanian Banjarbaru. p. 1320-1327.

Suwanti, L. T., N. D. R. Lastuti, E. Suprihati, dan Mufasirin. 2011. Petunjuk dan Laporan Praktikum Ilmu Penyakit Protozoa. Departemen Parasitologi Fakultas Kedokteran Hewan Universitas Airlangga.3-4.

Suwanti, L. T., N. D. R. Lastuti, E. Suprihati dan Mufasirin. 2012. Buku Ajar Protozoologi Veteriner. Airlangga University Press. Surabaya. 49-58.

Taylor, M. A., R. L. Coop, and R. L. Wall. 2007. Veterinary Parasitology. $3^{\text {rd }}$. ed. Blackwell Publishing. Oxford. xviii.

Wibowo, R. J. 2014. Kajian Penyakit Parasit Darah pada Sapi Potong di Kecamatan Cipatujah, Kabupaten Tasikmalaya, Jawa Barat [Skripsi]. Fakultas Kedokteran Hewan. Institut Pertanian Bogor. Hal. 6 11. 